\begin{tabular}{lll}
\hline Jurnal Pendidikan Dasar Perkhasa & \\
& & P-ISSN 2461-078X \\
Ettp://jurnal.stkippersada.ac.id/jurnal/index.php/JPDP/ & & \\
\hline
\end{tabular}

\title{
EFEKTIVITAS MODEL PEMBELAJARAN INQUIRY LEARNING DAN DISCOVERY LEARNING DITINJAU DARI SIKAP ILMIAH SISWA PADA MUATAN PEMBELAJARAN IPABAGI SISWA KELAS 5 SD
}

\author{
Erika Ayu Anggraini*1, Gamaliel Septian Airlanda² \\ 1,2Program Studi PGSD, Universitas Kristen Satya Wacana \\ Diterima: 20 Maret 2019. Dipublikasi: 5 April 2019.
}

\begin{abstract}
This study aims to determine the difference in effectiveness of Inquiry Learning and Discovery Learning models in terms of student' scientific attitude in natural science subject for $5^{\text {th }}$ grade student. The subject in this study is $5^{\text {th }}$ grade students of SD Negeri 1 Jelok and SD Negeri Randu. This study was included in a quasi-experimental research using a non-equivalent control group design approach. The variables in this study consisted of independent variables namely Inquiry Learning and Discovery Learning models and the dependent variable was students' scientific attitudes. The data collection techniques used wasa questionaire. In analyzing the data, different test were carried out throughtthe Independent Samples T-Test. The results of the different tests showed a significance value (2-tailed) the final condition questionnaire of students' scientific attitudes of 0,000 smaller than $0,005(0,000<0,005)$ so it was concluded that there were significant effectiveness differences between Inquiry Learning and Discovery Learning models in terms of students' scientific attitudes in natural science subject for $5^{\text {th }}$ grade students.Outcome of averages finalcondition questionnaire score of student' scientific attitude from $1^{\text {th }}$ experimental class greater than the $2^{\text {nd }}$ experimental classso it can be concluded that Inquiry Learning model is more effective than the treatment of Discovery Learning models in terms of student'scientific attitude .
\end{abstract}

Keyword: Effectiveness, Inquiry Learning, Discovery Learning, Student' Scientific Atitude.

Abstrak. Penelitian ini bertujuan untuk mengetahui perbedaan efektivitasmodel pembelajaran Inquiry Learningdan Discovery Learning ditinjau dari sikap ilmiah siswa pada muatan pembelajaran IPA bagi siswa kelas 5 SD. Subyek dalam penelitian iniadalah siswa kelas 5 SD Negeri 1 Jelok dan SD Negeri Randu. Penelitian ini termasuk dalam penelitian eksperimental semu yang menggunakan pendekatan non-equivalent control group design. Variabel dalam penelitian ini terdiri atas variabel bebas yakni model pembelajaran Inquiry Learning dan Discovery Learning dan variabel terikat yakni sikap ilmiah siswa. Teknik pengumpulan data yang digunakan adalah angket. Dalam menganalisis data dilaksanakan uji beda melaluiIndependent Sampel T-Test. Hasil uji beda menunjukkan nilai signifikansi (2-tailed) angket kondisi akhir sikap ilmiah siswa sebesar 0,000 lebih kecil dari $0,005(0,000<0,005)$ sehingga disimpulkan bahwa terdapat perbedaan efektivitas yang signifikan antara model pembelajaran Inquiry Learning dan Discovery Learningditinjau dari sikap ilmiah siswa pada muatan pembelajaran IPA bagi siswa kelas 5 SD. Hasil skor rata - rata kondisi akhir sikap ilmiah siswa kelas eksperimen 1 lebih besar dibandingkan dengan kelas eksperimen 2 sehingga dapat disimpulkan bahwa model pembelajaran Inquiry Learning lebih efektifdibandingkan dengan perlakuan berupa model pembelajaran Discovery Learning ditinjau dari sikap imiah siswa.

Kata Kunci: Efektivitas, Inquiry Learning, Discovery Learning, Sikap Ilmiah Siswa. 


\section{Pendahuluan}

Kegiatan yang lekat dalam dunia pendidikan adalah pembelajaran. Pembelajaran didefinisikan sebagai perilaku dan kapasitas seseorang yang dipengaruhi oleh pengalaman masa lalunya. Huda (2013: 6) mendefinisikan pembelajaran ke dalam dua konsep yakni pembelajaran sebagai perubahan perilaku dan perubahan kapasitas. Hausstater dan Nordkvelle (dalam Huda, 2013:5-6) mendefinisikan lebih lanjut tentang pembelajaran ke dalam tiga konsep, diantaranya: 1) Pembelajaran merupakan hal yang terjadi dalam diri manusia secara psikologis; 2) Interaksi antara individu dengan lingkungannya;

3) Respon pengalaman atas interaksi antara individu dengan lingkungan merupakan. Gasong (2018:5) turut mengungkapkan pendapatnya mengenai pembelajaran yang ia jabarkan sebagai rancangan dari seperangkat peristiwa yang mendukung, memprakarsai, dan menggiatkan kegiatan belajar siswa yang melalui proses perancangan dan penyajian peristiwa. Berdasarkan pendapat beberapa ahli tersebut dapat ditarik kesimpulan bahwa pembelajaran merupakan sebuah proses penyesuaian dan perubahan yang dilakukan oleh siswa sebagai respon terhadap interaksinya dengan lingkungan belajarnya baik secara fisik maupun psikologis yang dirancang dan disajikan oleh guru.

Dalam merancang dan menyajikan pembelajaran, guru senantiasa menyesuaikan dengan perubahan dan perkembangan Kurikulum. Kurikulum yang berlaku saat ini yakni Kurikulum 2013 yang menitikberatkan pada pengalaman siswa dalam mengkonstruksi pengetahuannya sendiri (student centered). Sejalan dengan Dewey (dalam Huda, 2013:39) yang mengungkapkan bahwa semua pengetahuan, pemikiran, dan pembelajaran dapat muncul melalui pengalaman.

Pengalaman yang dimaksud dapat berupa penemuan konsepkonsep yang dilakukan oleh siswa. Dalam proses mencari dan menemukan konsep, siswa memerlukan sikap yang akan membuat penemuan mereka menjadi lebih bermakna. Sikap yang identik dengan penemuan adalah sikap ilmiah. Sikap ilmiah tidak hanya 
dimiliki oleh seorang ahli namun juga perlu dimiliki oleh siswa. Hendracipta (2016) mengemukakan bahwa sikap ilmiah diartikan sebagai kecenderungan seseorang berupa penerimaan maupun penolakan terhadap cara berpikir yang sesuai dengan dasar ilmu pengetahuan. Harlens (dalam Herson Anwar, 2009:107-108) mengelompokkan sikap ilmiah yang dapat diamati selama proses pembelajaran ke dalam tujuh dimensi sikap ilmiah, diantaranya: 1) Curiosity (sikap ingin tahu); 2) Respect for Evidence (sikap peduli terhadap sebuah data/fakta); 3) Critical Reflection (Sikap refleksi diri secara kritis); 4) Perseverance (sikap tekun); 5) Cooperation with others (sikap dapat bekerjasama); 6) Creativity and inventiveness (sikap kreatif dan penemuan); 7) Sensitivity to environment (sikap peduli lingkungan). Dari ketujuh dimensi sikap ilmiah tersebut, dirangkum ke dalam empat sikap ilmiah yang paling esensial, diantaranya: 1) rasa ingin tahu; 2) jujur; 3) tekun; 4) kritis.

Melihat dari pentingnya sikap ilmiah bagi siswa, menimbulka kesadaran bagi penanaman sikap ilmiah siswa. Penanaman sikap Imiah secara optimal dilakukan melalui muatan pembelajaran IPA. Hal ini dikarenakan muatan pembelajaran IPA dapat menanamkan sekaligus melatih siswa memecahkan masalah yang dihadapinya menggunakan metode ilmiah (Sumaji dalam Awang, 2012: 26). Sejak awal penerapannya, IPA sebagai muatan pembelajaran yang berdiri sendiri. Namun sejak ditetapkan Kurikulum Tahun 2013, IPA terintegrasi dengan muatan pembelajaran lain. IPA terintegrasi dengan muatan pembelajaran wajib di SD diantaranya PKN, Bahasa Indonesia, IPA, SBdP, dan PJOK. Hal ini tercantum dalam Lampiran Permen No. 57 Tahun 2014 Tentang Kurikulum $2013 \quad$ Sekolah Dasar/Madrasah Ibtidaiyah. Dalam mengajarkan muatan pembelajaran IPA, guru memerlukan model pembelajaran yang memfasilitasi terlaksananya metode ilmiah. Model pembelajaran didefinisikan sebagai pola, rencana, atau rancangan kurikulum, mendesain materi - materi instruksional, dan memandu proses pengajaran di ruang kelas atau di seting yang berbeda (Joyce dan Weill, 2009:7). Model pembelajaran yang tepat yang mampu memfasilitasi 
terlaksananya metode ilmiah guna memunculkan sikap ilmiah adalah model berbasis penemuan. Model berbasis penemuan tersebut yakni model pembelajaran Inquiry Learning dan Discovery Learning. Sanjaya (2016:196) mengemukakan bahwa model pembelajaran Inquiry Learning adalah suatu model yang memungkinkan siswa mencari dan menemukan sendiri jawaban atas permasalahan dalam pembelajaran melalui pola pikir analitis dan kritis.Sedangkan Discovery Learning didefinisikan sebagai model pembelajaran merupakan model yang mencoba menghadapkan masalah yang telah direkayasa oleh guru kepada siswa agar siswa mampu mengorganisasi sendiri jawaban dari masalah tersebut (Kurniasih, 2014:64).

Inquiry Learning dan Discovery Learningrupakan model pembelajaran yang memiliki prinsip dan karakteristik yang sama. Brunner (dalam Direktorat Pembinaan Sekolah Dasar, 2016:60-61), mengemukakan bahwa tidak ada perbedaan yang prinsipil antara kedua model tersebut. Sebagai model pembelajaran, Inquiry Learning dan Discovery Learning memiliki prinsip yang sama. Inquiry Learning dan Discovery Learning memiliki kesamaan dalam hal penekanan pada penemuan konsep atau prinsip oleh siswa sendiri yang sebelumnya tidak diketahui. Persamaan lain yakni kedua model ini tidak menyajikan bahan ajar dalam bentuk final. Sehingga dapat mendorong siswa untuk menemukan sendiri konsep yang dibutuhkannya. Jika dilihat dari sintak pembelajaran, kedua model ini memiliki sintak yang sama. Tidak banyak perbedaan yang terdapat antara model pembelajaran Inquiry Learning dan Discovery Learning. Perbedaan terletak pada penyajian masalah yang dihadapkan pada siswa. Pada model pembelajaran Inquiry Learning masalah yang dihadapkan kepada siswa merupakan masalah yang dirumuskan oleh siswa sendiri. Sehingga segenap pikiran dan keterampilan, dan sikap yang dibutuhkan guna mendapatkan temuan-temuan di dalam masalah tersebut melalui proses penelitian. Sedangkan dalam model Discovery Learning masalah yang dihadapkan pada siswa merupakan masalah yang sudah direkayasa oleh guru sehingga tidak banyak memerlukan 
keterlibatan pikiran, keterampilan, dan sikap yang dibutuhkan siswa dalam penemuan tidak jika dibandingkan dengan model pembelajaran Inquiry Leaning. Selain itu, pada model pembelajaran Inquiry Learning pengetahuan dan keterampilan siswa tidak dibatasi oleh guru. Sedangkan dalam model pembelajaran Discovery Learning, pikiran dan keterampilan siswa terbatas pada rekayasa yang dilakukan guru pada masalah yang dihadapkan kepada siswa. Model pembelajaran Inquiry Learning dan Discovery Learning pada prinsipnya tidak memiliki perbedaan yang signifikan. Berdasarkan uraian Brunner, dapat diketahui bahwa perbedaan hanya terletak ada penyajian konsep materi pembelajaran saja.

Berdasarkan fakta tersebut, munculah keragu-raguan peneliti apakah model yangsama dari segi prinsip dan karakteristik memiliki efektivitas yang berbeda secara signifikan bagi sikap ilmiah siswa. Efektivitas sebuah model dapat dilihat dari tingkat ketercapaian tujuan pembelajaran dengan menggunakan model (Popham dalam
Koloi-Keaikitse, 2016). Berdasarkan hal ini, peneliti tertarik menelitiperbedaan Efektivitas Model Pembelajaran Inquiry Learning Dan Discovery Learning Ditinjau Dari Sikap Ilmiah Siswa Pada Muatan Pembelajaran IPA Bagi Siwa Kelas 5 SD.

\section{Metode \\ Jenis penelitian yang akan} diterapkan dalam penelitian ini adalah eksperimental-semu (quasieksperimental reserach).Informasi yang didapatkan melalui penelitian ini merupakan perkiraan dariinformasi yang diperoleh melalui eksperimen yang sebenarnya (eksperimental murni/true-eksperimental reserach) dalam keadaan yang tidak memungkinkan pengontrolan atau pemanipulaisan terhadap variabelvariabel yang relevan (Slameto, 2014:100). Desain penelitian yang akan diterapkan dalam penelitian ini adalah eksperimental-semu (quasieksperimental reserach) dengan pola pendekatan non-equivalent control group design.Berikut akan disajikan bagan dari desain penelitian dengan pola pendekatan non-equivalent control group design. 


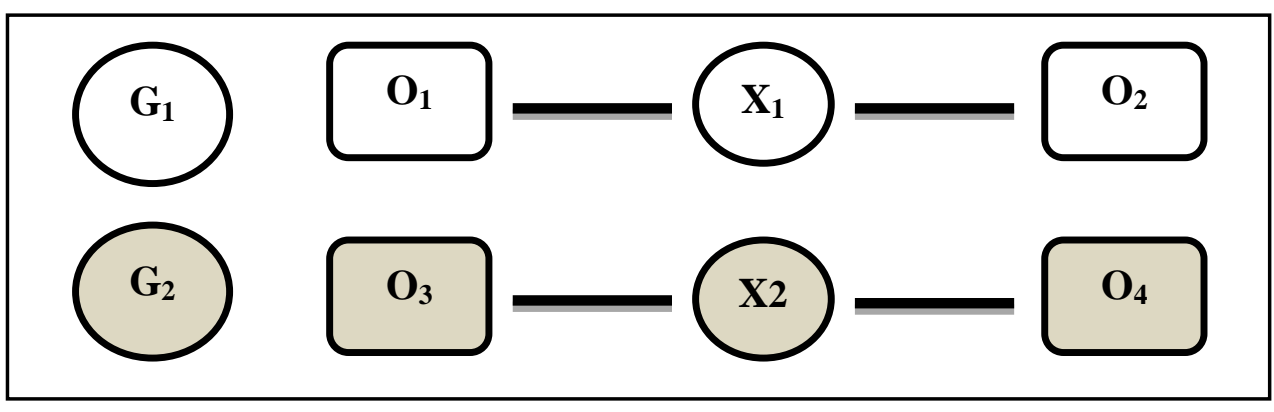

\section{Gambar 1. Desain Penelitian Non-Equivalent Control Group Design (Musfiqon, 2012)}

Populasi dalam penelitian ini terdiri dari seluruh siswa kelas 5 SD Negeri 1 Jelokdanseluruh siswa kelas 5 SD Negeri Randu Gugus Diponegoro II pada Tahun ajaran 2018/2019. Kedua Sekolah ini terletak di Kelurahan Jelok, Kecamatan Cepogo, Kabupaten Boyolali. Sampel dalam penelitian ini adalah siswa kelas 5 SD Negeri 1 Jelok sebagai kelas eksperimen 1 yang berjumlah 17 siswa. Sebagai kelas eksperimen 2, penelitian ini mengambil sampel siswa kelas 5 SD Negeri Randu yang berjumlah 20 siswa. Teknik pengambilan sampeldalam penelitian ini adalahsimple random sampling.

Dalam penelitian ini variabel bebas yang diteliti adalah model pembelajaran Inquiry Learning yang diberikan pada kelompok eksperimen 1. Sedangkan kelompok eksperimen 2 akan diberikan perlakuan dengan penggunaan model pembelajaran Discovery Learning. Variabel terikat dalam penelitian ini adalah sikap ilmiah siswa. Data yang diperoleh dalam penelitian ini berupa hasil angket sikap ilmiah. Data penelitian diperoleh dengan menggunakan instrumen pengambilan data yakni angket kondisi awal dan kondisi akhir sikap ilmiah siswa. Data yang diperoleh akan dianalisis dengan menggunakan serangkaian uji diantaranya uji prasyarat yakni uji normalitas dan uji homogenitas, uji beda, dan uji hipotesis.

\section{Hasil dan Pembahasan}

Hasil penelitian terdiri dari hasil analisis uji prasyarat, analisis data, dan analisis uji hipotesis. Uji prasyarat terdiri dari uji normalitas dan uji homogenitas. Uji normalitas dilakukan guna mengetahui apakah data berdistribusi secara normal atau tidak. Tujuan dari uji homogenitas yakni guna mengetahui ada atau tidaknya kesamaan antara dua data atau lebih yang didistribusikan. Pengujian dilakukan pada perolehan skor angket kondisi awal dan angket kondisi akhir sikap ilmiah siswa baik pada kelas eksperimen 1 maupun kelas 
eksperimen 2. Hasil uji normalitas dapat

dilihat

melalui

tabel 1 dan 2

Tabel 1. Hasil Uji Normalitas Data Angket Kondisi Awal Sikap Ilmiah Siswa Tests of Normality

\begin{tabular}{llc|c|ccc|c|c} 
& Kelas & \multicolumn{3}{c}{ Kolmogorov-Smirnova } & \multicolumn{3}{c}{ Shapiro-Wilk } \\
\cline { 2 - 8 } & & Statistic & df & Sig. & Statistic & df & Sig. \\
\hline $\begin{array}{l}\text { Kondisi Awal } \\
\begin{array}{l}\text { Sikap Ilmiah } \\
\text { Siswa }\end{array}\end{array}$ & $\begin{array}{l}\text { Lksperimen 1 (Inquiry } \\
\text { Learning) }\end{array}$ & $\begin{array}{l}\text { Eksperimen 2 } \\
\text { (Discovery Learning) }\end{array}$ & .167 & 17 & $.200^{*}$ & .931 & 17 & .226 \\
\hline
\end{tabular}

Berdasarkan tabel 1 dapat Pada kelas eksperimen 2 uji diketahui bahwa uji normalitas normalitas menunjukkan nilai menunjukkan nilai signifikansi pada kondisi awal sikap ilmiah siswa kelas eksperimen 1 sebesar 0,200 pada signifikansi sebesar 0,200 pada Kolmogrov-Smirnov dan 0,857 pada Shapiro-Wilk. Nilai signifikansi 0,200 dan Kolmogrov-Smirnov dan 0,226 pada Shapiro-Wilk. Nilai signifikansi 0,200 dan 0,226 lebih besar dari 0,005 $((0,200>0,005)(0,226>0,005))$ sehingga dapat disimpulkan bahwa sebaran data pada angket kondisi awal kelas 0,857 merupakan nilai signifikansi yang lebih dari 0,005 ((0,200>0,005) $(0,857>0,005)) \quad$ sehingga dapat disimpulkan bahwa sebaran data pada angket kondisi awal kelas eksperimen 2 dinyatakan normal. eksperimen 1 dinyatakan normal.

Tabel 2. Hasil Uji Normalitas Data Angket Kondisi Akhir Sikap Ilmiah Siswa Tests of Normality

\begin{tabular}{llllllll} 
& \multicolumn{1}{c}{ Kelas } & \multicolumn{3}{c}{ Kolmogorov-Smirnov } & \multicolumn{4}{c}{ Shapiro-Wilk } \\
& & Statistic & df & Sig. & Statistic & df & Sig. \\
\hline $\begin{array}{l}\text { Kondisi Akhir } \\
\begin{array}{l}\text { Sikap Ilmiah } \\
\text { Siswa }\end{array}\end{array}$ & $\begin{array}{l}\text { Kelas Eksperimen 1 } \\
\text { (Inquiry Learning) }\end{array}$ & .097 & 17 & $.200^{*}$ & .962 & 17 & .664 \\
& $\begin{array}{l}\text { Kelas Eksperimen 2 } \\
\text { (Discovery Learning) }\end{array}$ & .130 & 20 & $.200^{*}$ & .949 & 20 & .355 \\
\hline
\end{tabular}

Berdasarkan tabel 2 dapat diketahui bahwa uji normalitas menunjukkan nilai signifikansi pada kondisi akhir sikap ilmiah siswa kelas eksperimen 1 sebesar 0,200 pada Kolmogrov-Smirnov dan 0,664 pada Shapiro-Wilk. Nilai signifikansi 0,200 dan
0,664 dari kelas eksperimen 1 merupakan nilai signifikansi yang lebih besar dari 0,005 $((0,200>0,005)$ $(0,664>0,005))$. Sehingga dapat disimpulkan bahwa sebaran data pada angket kondisi akhir kelas eksperimen 1 dinyatakan normal. 
Pada kelas eksperimen 2 uji angket kondisi akhir kelas eksperimen 2 normalitas menunjukkan nilai signifikansi sebesar 0,200 pada dinyatakan normal.

Kolmogrov-Smirnov dan 0,355 pada Dengan cara yang sama dilakukan Shapiro-Wilk. Nilai signifikansi 0,200 dan 0,355 pada kelas eksperimen 2 merupakan nilai signifikansi yang lebih besar dari 0,005 $((0,200>0,005)$ $(0,355>0,005)) \quad$ sehingga dapat disimpulkan bahwa sebaran data pada homogenitas.

Tabel 3. Hasil Uji Homogenitas Angket Kondisi Awal Sikap Ilmiah Siswa Test of Homogeneity of Variances

\begin{tabular}{cccc}
\hline Levene Statistic & df1 & df2 & Sig. \\
\hline 3.971 & 1 & 35 & .054 \\
\hline
\end{tabular}

Tabel 3 menyajikan hasil uji 0,054. Nilai signifikansi 0,054 lebih dari homogenitas untuk skor angket kondisi $0,005(0,054>0,005)$ sehingga dapat awal sikap ilmiah siswa baik pada kelas eksperimen 1 maupun kelas eksperimen 2. Berdasarkan tabel di atas didapatkan hasil dengan nilai signifikansi sebesar disimpulkan bahwa data angket kondisi awal sikap ilmiah siswa baik pada kelas eksperimen 1 maupun kelas eksperimen 2 dinyatakan homogen.

\section{Tabel 4. Hasil Uji Homogenitas Angket Kondisi Akhir Sikap Ilmiah Siswa Test of Homogeneity of Variances}

\begin{tabular}{cccc}
\hline Levene Statistic & df1 & df2 & Sig. \\
\hline .456 & 1 & 35 & .504 \\
\hline
\end{tabular}

Berdasarkan tabel 4 didapatkan hasil uji homogenitas data angket kondisi akhir sikap ilmiah siswa baik pada kelas eksperimen 1 maupun kelas eksperimen 2. Hasil uji homogenitas menunjukkan nilai siginifikansi sebesar
0,504. Nilai signifikansi 0,504 lebih besar dari $0,005(0,504>0,005)$ sehingga dapat disimpulkan bahwa data angket kondisi akhir sikap ilmiah siswa pada kedua kelas dinyatakan homogen. 
Data hasil uji normalitas dan homogenitas angket kondisi awal dan kondisi akhir sikap ilmiah baik pada kelas eksperimen 1 maupun kelas eksperimen 2 dianalisis menjadi data statistik dekriptif. Data pada tabel statistik deskriptif dianalisis guna mengetahui model pembelajaran yang paling unggul jika ditinjau dari hasil ratarata kondisi akhir angket sikap ilmiah siswa. Hasil analisis mencakup data angket kondisi awal dan kondisi akhir sikap ilmiah siswa baik pada kelas eksperimen 1 maupun kelas eksperimen 2. Hasil analisis data disajikan pada tabel 5 berikut ini.

\section{Tabel 5. Hasil Analisis Deskriptif Angket Sikap Ilmiah Siswa}

\begin{tabular}{lcccc}
\hline & \multicolumn{2}{c}{ Kondisi Awal } & \multicolumn{2}{c}{ Kondisi Akhir } \\
& Ekperimen 1 & Eksperimen 2 & Ekperimen 1 & Eksperimen 2 \\
\hline N & 17 & 20 & 17 & 20 \\
Mean & 125,76 & 109,65 & 145,35 & 133,80 \\
Std. & & & & \\
Deviation & 7,579 & 4,464 & 9,798 & 8,115 \\
Lower & 12,037 & 11,807 & 5,577 & 5,456 \\
Upper & 20,192 & 20,423 & 17,529 & 17,649 \\
\hline
\end{tabular}

Berdasarkan data yang terdapat pada tabel 5 dapat diketahui bahwa hasil rata-rata/mean pada kondisi akhir sikap ilmiah siswa pada kelas eksperimen 1 sebesar 145,35 dan kondisi akhir sikap ilmiah siswa pada kelas eksperimen 2 sebesar 133,80. Berdasarkan hasil analisis skor angket kondisi akhir sikap ilmiah pada kelas eksperimen 1 yang menggunakan model pembelajaran Inquiry Learningmemiliki rata-rata lebih tinggi dari rata-rata skor angket kondisi akhir kelas eksperimen 2 dengan menggunakan model pembelajaran Discovery Learning $(145,35>133,80)$. Efektivitas model pembelajaran Inquiry
Learning dan Discovery Learning dapat dilihat perbandingan antara rata-rata skor angket kondisi akhir dari kelas eksperimen 1 dan kelas eksperimen 2.

Hasil kondisi akhir sikap ilmiah yang diperoleh di SD Negeri 1 Jelok sebagai kelas eksperimen 1 dengan memberikan perlakuan berupa model pembelajaran Inquiry Learning dinyatakan lebih unggul dibandingkan dengan hasil kondisi ahir sikap ilmiah yang diperoleh melalui pembelajaran dengan memberikan model pembelajaran Discovery Learningdi SD Negeri Randu sebagai kelas eksperimen 2. Model pembelajaran Inquiry Learning 
yang diberikan di SD Negeri 1 Jelok dinyatakan lebih unggul dibandingkan dengan model pembelajaran model pembelajaran Discovery Learning yang diberikan di SD Negeri Randu disebabkan oleh beberapa alasan yang menjadi kelebihan model pembelajaran Inquiry Learning seperti yang dikemukakan oleh Sanjaya (2016:208), sebagai berikut: 1) Pembelajaran dengan model ini menjadi lebih bermakna karena menitikberatkan pada keseimbangan pengembangan aspek kognitif, afektif, dan psikomotor siswa; 2) Siswa diberikan kesempatan untuk belajar sesuai dengan gaya belajar masing-masing; 3) Berorientasi pada anggapan bahwa pengalaman terbentuk melalui proses perubahan tingkah laku sebagai inti dari pembelajaran yang merupakan perkembangan dari psikologi belajar moderen; 4) siswa yang memiliki kemampuan belajar yang rendah tidak akan menghambat siswa dengan kemampuan belajr tingi karena model pembelajaran Inquiry Learning lebih dapat memfasilitasi siswa dengan kemampuan belajar tinggi. Dalam model pembelajaran Inquiry Learning terdapat beberapa sintak yang memberikan kesempatan bagi penanaman sikap ilmiah siswa terutama pada aspek rasa ingin tahu, jujur, kritis dan tekun dapat ditanamkan karena keseluruhan sintak dilaksanakan oleh siswa tanpa campur tangan dan rekayasa guru.Sintak tersebut diantaranya: 1) orientasi; 2)merumukan masalah; 3) merumuskan hipotesis; 4) mengumpulkan data; 5) menguji hipotesis; 6) merumuskan kesimpulan.

Setelah data penelitian dinyatakan normal dan homogen melalui uji normalitas dan uji homogenitas, akan dilakukan uji hipotesis dengan analisis parametik melalui uji t. Uji t dilakukan malalui uji independent sample t-test dengan bantuan software SPSS version 20.0. Uji t dilakukan untuk mengetahui perbedaan rata - rata kondisi awal sikap ilmiah siswa dan kondisi akhir sikap ilmiah siswa baik pada kelas eksperimen 1 maupun kelas eksperimen 2. Hasil uji t kondisi awal dan kondisi akhir sikap ilmiah siswa pada kedua kelas dapat dilihat pada tabel 6 dan 7 di bawah ini. 
Tabel 6. Uji T Kondisi Awal Sikap Ilmiah Siswa

Independent Samples Test

\begin{tabular}{|c|c|c|c|c|c|c|c|c|c|c|}
\hline & & \multicolumn{2}{|c|}{$\begin{array}{c}\text { Levene's Test } \\
\text { for Equality } \\
\text { of Variances }\end{array}$} & \multicolumn{7}{|c|}{ t-test for Equality of Means } \\
\hline & & \multirow[t]{2}{*}{$\mathbf{F}$} & \multirow[t]{2}{*}{ Sig. } & \multirow[t]{2}{*}{$\mathbf{t}$} & \multirow[t]{2}{*}{ df } & \multirow[t]{2}{*}{$\begin{array}{l}\text { Sig. (2- } \\
\text { tailed) }\end{array}$} & \multirow[t]{2}{*}{$\begin{array}{c}\text { Mean } \\
\text { Differe } \\
\text { nce }\end{array}$} & \multirow{2}{*}{$\begin{array}{l}\text { Std. } \\
\text { Error } \\
\text { Differ } \\
\text { ence }\end{array}$} & \multicolumn{2}{|c|}{$\begin{array}{l}\text { 95\% Confidence } \\
\text { Interval of the } \\
\text { Difference }\end{array}$} \\
\hline & & & & & & & & & Lower & Upper \\
\hline $\begin{array}{l}\text { Kondisi } \\
\text { Awal } \\
\text { Sikap }\end{array}$ & $\begin{array}{c}\text { Equal } \\
\text { variances } \\
\text { assumed } \\
\text { Equal }\end{array}$ & 3.971 & .054 & 8.023 & 35 & .000 & 16.115 & 2.009 & 12.037 & 20.192 \\
\hline $\begin{array}{l}\text { Ilmiah } \\
\text { Siswa }\end{array}$ & $\begin{array}{l}\text { variances } \\
\text { not } \\
\text { assumed }\end{array}$ & & & 7.704 & 24.996 & .000 & 16.115 & 2.092 & 11.807 & 20.423 \\
\hline
\end{tabular}

Tabel 6 menunjukkan hasil uji $\mathrm{t}$ sebesar 0,000 lebih kecil dari 0,005 yang dapat dilihat melalui kolom equal $\quad(0,000<0,005)$. Berdasarkan dasar variances assumed. Pada kolom equal pengambilan keputusan nilai variances assumed menunjukkan nilai signifkansi (2-tailed) kondisi awal t sebesar 8,023. Melalui kolom equal sikap ilmiah siswa dinyatakan variances assumed juga dapat terdapat perbedaan rata-rata yang diketahui nilai signifiknasi (2-tailed) signifikan antara kondisi awal sikap kondisi awal sikap ilmiah siswa imiah siswa pada kelas eksperimen 1 sebesar 0,000. Nilai signifikansi (2- dan kelas eksperimen 2. tailed) kondisi awal sikap ilmiah siswa

Tabel 7. Uji T Kondisi Akhir Sikap Ilmiah Siswa Independent Samples Test

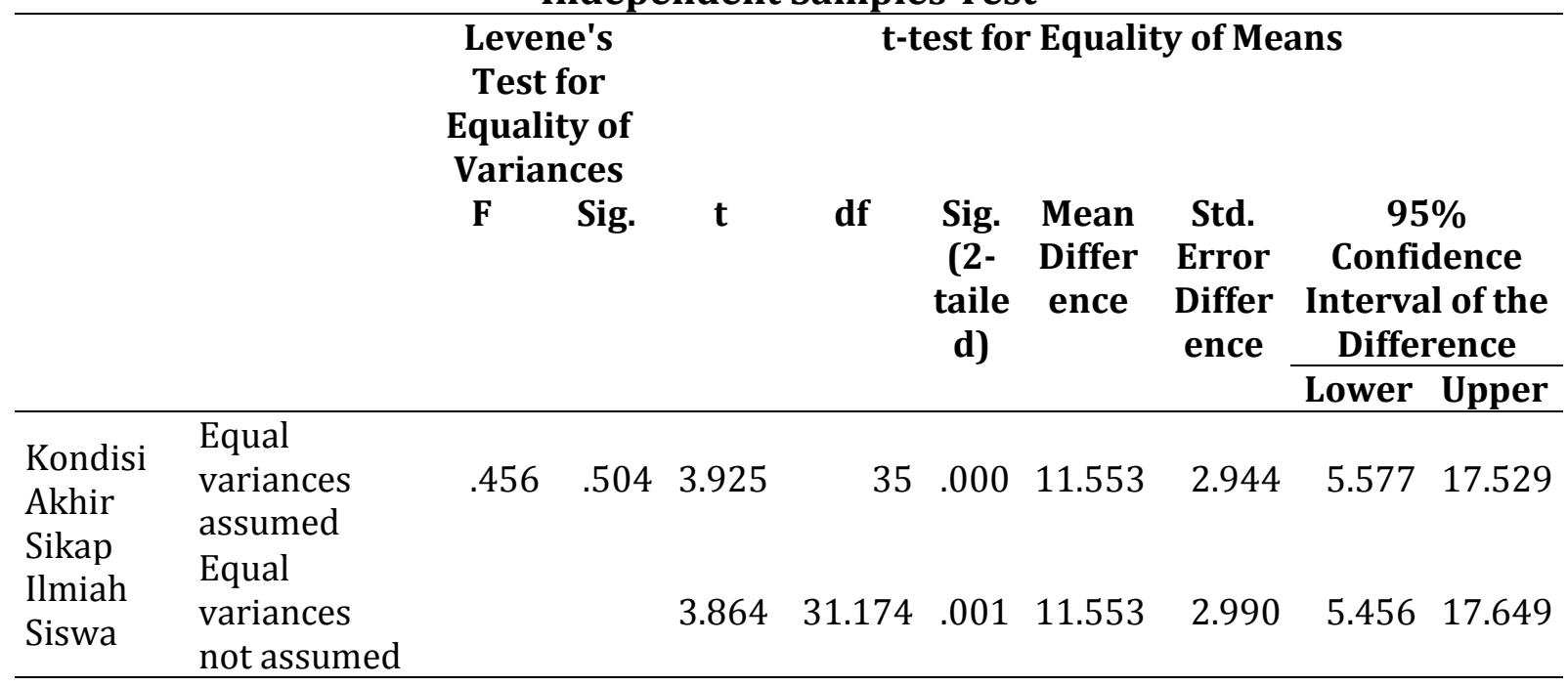


Tabel 7 menunjukkan hasil uji $\mathrm{t}$ yang dapat dilihat melalui kolom equal variances assumed. Pada kolom equal variances assumed menunjukkan nilai t sebesar 3,925. Melalui kolom equal variances assumed juga dapat diketahui nilai signifiknasi (2-tailed) kondisi akhir sikap ilmiah siswa sebesar 0,000. Nilai signifikansi (2tailed) kondisi akhir sikap ilmiah siswa sebesar 0,000 lebih kecil dari $0,005 \quad(0,000<0,005) \cdot$ Berdasarkan dasar pengambilan keputusan nilai signifkansi (2-tailed) kondisi akhir sikap ilmiah siswa dinyatakan terdapat perbedaan rata-rata yang signifikan antara kondisi akhir sikap imiah siswa pada kelas eksperimen 1 dan kelas eksperimen 2. Berdasarkan hasil analisis data dalam tabel 7 pada kolom sign. (2-tailed) dilakukan uji hipotesis.Hipotesis dalam penelitian ini yakni:

$$
\mathrm{H}_{0} \text { : Tidak terdapat }
$$
perbedaan efektivitas yang signifikan antara model pembelajaran Inquiry Learning dan Discovery Learning ditinjau dari sikap ilmiah siswa pada muatan pembelajaran IPA bagi siswa kelas 5 SD.

$\mathrm{H}_{\mathrm{a}}$ : Terdapat perbedaan efektivitas yang signifikan antara model pembelajaran Inquiry Learning dan Discovery Learningditinjau dari sikap ilmiah siswa pada muatan pembelajaran IPA bagi siswa kelas 5 SD.

Perbedaan efektivitas dapat dilihat dari nilai signifikansi (2-tailed) atas hasil uji beda rata-rata pada tabel 7 bagian kolom t-test for Equality of Means. Pengambilan keputusan perbedan efektivitas didasarkan pada nilai signifikansi (2-tailed) atas $\mathrm{H}_{0}$ dan $\mathrm{H}_{\mathrm{a}}$. Jika $\mathrm{H}_{0}$ menunjukkan nilai signifikansi (2-tailed) lebih besar dari $0,005(>0,005)$ maka tidak terdapat perbedaan efektivitas yang signifikan antara model pembelajaran Inquiry Learning dan Discovery Learning ditinjau dari sikap ilmiah siswa pada muatan pembelajaran IPA bagi siswa kelas 5 SD. Dan jika $\mathrm{H}_{\mathrm{a}}$ menunjukkan nilai signifikansi (2-tailed) lebih kecil dari $0,005(<0,005)$ maka terdapat perbedaan efektivitas yang signifikan antara model pembelajaran Inquiry Learning dan Discovery Learning ditinjau dari sikap ilmiah siswa pada muatan pembelajaran IPA bagi siswa kelas 5 SD. Berdasarkan hasil uji tpada tabel 7dalam kolom t-test for Equality of Means menunjukkan signifikansi (2tailed) sebesar 0,000, dan nilai 
tersebut lebih besar dari 0,005 $(0,000<0,005)$ sehingga dapat ditarik kesimpulan bahwa $\mathrm{H}_{\mathrm{a}}$ diterima dan artinya bahwa terdapat perbedaan efektivitas yang signifikan antara model pembelajaran Inquiry Learning dan Discovery Learning ditinjau dari sikap ilmiah siswa pada muatan pembelajaran IPA bagi siswa kelas 5 SD.

\section{Simpulan}

Hasil analisis data penelitian mengarah pada kesimpulan bahwa terdapat perbedaan efektivitas yang signifikan antara model pembelajaran Inquiry Learning yang dilaksanakan di SD Negeri 1 Jelok dan Discovery Learning yang dilaksankan di SD Negeri Randu ditinjau dari sikap ilmiah siswa pada muatan pembelajaran IPA bagi siswa kelas 5 SD. Kesimpulan tersebut telah dibuktikan melalui uji hipotesis berdasarkan analisis parametrik menggunakanuji t. Hasil uji $t$ menunjukkan hasil uji $\mathrm{t}$ diperoleh nilai $t_{\text {hitung }}$ sebesar 3,925 kolom pada equal variances assumed. Melalui kolom equal variances assumed juga dapat diketahui nilai signifiknasi (2tailed) kondisi akhir sikap ilmiah siswa sebesar 0,000. Nilai signifikansi (2-tailed) kondisi akhir sikap ilmiah siswa sebesar 0,000 lebih kecil dari $0,005 \quad(0,000<0,005)$. Berdasarkan dasar pengambilan keputusan nilai signifkansi (2-tailed) kondisi akhir sikap ilmiah siswa dinyatakan terdapat perbedaan rata - rata yang signifikan antara kondisi akhir sikap imiah siswa pada kelas eksperimen 1 dan kelas eksperimen 2 dengan mean difference sebesar 11,553.

Selain itu, hasil skor rata - rata kondisi akhir sikap ilmiah siswa pada kelas eksperimen 1 dan kelas eksperimen 2 menujukkan perbedaan yang cukup signifikan. Kelas eksperimen 1 dengan menggunakan model pembelajaran Inquiry Learning memiliki skor rata-rata kondisi akhir sikap ilmiah sebesar 145,35. Sedangkan skor rata - rata kondisi akhir pada kelas eksperimen 2 yang menggunakan model pembelajaran Discovery Learning sebesar 133,80. Skor rata - rata kondisi akhir sikap ilmiah siswa kelas eksperimen 1 lebih besar dibandingkan dengan skor rata - rata kondisi akhir sikap ilmiah siswa kelas eksperimen $2(145,35>133,80)$. Berdasarkan hal itu, dapat disimpulkan bahwa sikap ilmiah siswa 
dalam muatan pembelajaran IPA materi perpindahan kalor di sekitar kita pada team 6 subtema 2 pada kelas eksperimen 1 dengan memberikan perlakuan berupa model pembelajaran Inquiry Learning lebih efektifdibandingkan dengan perlakuan berupa model pembelajaran Discovery Learning.

\section{Daftar Pustaka}

Anwar, H. (2009). Penilaian sikap llmiah dalam pembelajaran sains. Jurnal Pelangi Ilmu, 2(5), 103-114

Awang, I. S. (2012). Pengembangan Subject SpesificPedagogy (SSP) Mata Pelajaran IPA Untuk MengembangkanKarakterPeserta Didik KelasII Sekolah Dasar (Doctoral dissertation, Tesis magister, tidak diterbitkan, Universitas Negeri Yogyakarta, Yogyakarta). Tersedia https://eprints.uny.ac.id/8211/

Dasar, D. P. (2016). Panduan Teknis Pembelajaran dan Penilaian di Sekolah Dasar. Jakarta: Kementrian Pendidikan dan Kebudayaan.

Gasong, D. (2018). Belajar dan pembelajaran. Deepublish.
Tersedia

https://books.google.co.id/book

$\underline{s ? h l=e n \& l r=\& i d=3 r l j D w A A Q B A I}$

\&oi=fnd\&pg=PA162\&dq=Belajar

$\underline{+ \text { dan }+ \text { pembelajaran\&ots=tkD9F }}$

GgjD1\&sig=r5KkRi3ze2IkUDF3o

$\underline{n t F O E c a 3 o w \& r e d i r ~ e s c ~}=y \# v=0 n$

epage \&q=Belajar $\% 20$ dan $\% 20$ pe $\underline{\text { mbelajaran \&f}=\text { false }}$

Hendracipta, N. (2016).

Menumbuhkan Sikap Ilmiah

Siswa Sekolah Dasar Melalui

Pembelajaran IPA Berbasis

Inkuiri. Jurnal Pendidikan

Sekolah Dasar, 2(1), 109-116.

Joyce, B., Wheil, \& Calhoun. (2009). Models Of Teaching. New Jersey: Prentice Hall Inc. Engledwodd Clifss.

Kurniasih, I., \& Sani, B. (2014). Implementasi Kurikulum 2013: Konsep \& Penerapan. Kata Pena. Koloi-Keaikitse, S. (2016). Assessment training: A precondition for teachers' competencies and use of classroom assessment practices. International Journal of Training and Development, 20(2), 107-123.

Musfiqon, H. M. (2012). Metodologi Penelitian Pendidikan. Jakarta: Prestasi Pustakaraya. 
Pendidikan, L. P. M., \& Nomor, K. R. I. (57). Tahun 2014 Tentang Kurikulum 2013 Sekolah Dasar/Madrasah Ibtidaiyah. Jakarta: Depdikbud.
Sanjaya, W. (2016). Strategi

Pembelajaran. Jakarta: Prenamedia Grup.

Slameto,M. (2014). Penelitian dan Inovasi Pendidikan. Salatiga:

Widya Sari Press.

